Check for updates

Cite this: RSC Adv., 2017, 7, 50794

\title{
Hydrothermal liquefaction of high protein microalgae via clay material catalysts $\dagger$
}

\author{
Wenjia Wang, (D) Shengdi Zhang, Qi Yu, Yutong Lin, Nianzi Yang, Wei Han \\ and Jinglai Zhang $(\mathbb{D}$ *
}

Hydrothermal liquefaction $(\mathrm{HTL})$ is a promising method to convert wet microalgae into a petroleum-like biocrude. In this paper, we demonstrated the HTL of microalgae Spirulina over various clay material catalysts and open up interesting perspectives for efficiently liquefaction processes. The clay catalyst successfully improved the biocrude yield, the liquefaction conversion, and energy recovery. Investigation into optimizing operation conditions suggested that the reaction temperature and holding time significantly influenced the HTL process. The highest biocrude yields were obtained at a reaction temperature within the range of $220-250{ }^{\circ} \mathrm{C}$ and a holding time of $30 \mathrm{~min}$ with montmorillonite (46.56\%), kaolinite (44.07\%) and dolomitic limestone (46.35\%). Adding clay catalysts changed the element content and produced more asphaltene content in the biocrude. The GC-MS analysis revealed that the catalyst greatly influenced the composition of the hydrocarbons, acids, esters, amides and heterocyclic compounds in the biocrude.

Received 27th July 2017

Accepted 25th October 2017

DOI: $10.1039 / \mathrm{c} 7 \mathrm{ra0} 8311 \mathrm{~d}$

rsc.li/rsc-advances

sulfur (1-2\%), which were much higher than those in petro-

\section{Introduction}

Environmental concerns about greenhouse gas emission and finite fossil fuel reserves persuaded humans to search for alternative renewable liquid fuels. ${ }^{1}$ As the third generation of biomass, microalgae can efficiently convert sunlight into chemical energy and presents the potential to be the feedstock in further thermochemical or biological conversion processes..$^{2-4}$ Among various kinds of processes, hydrothermal liquefaction (HTL) could be a promising method to produce liquid biofuels from microalgae. ${ }^{5}$

The HTL of microalgae is the thermochemical process which turns microalgae biomass into liquid biocrude and other byproducts in an oxygen-isolated reactor with inert gases or reducing gases, at certain temperature $\left(200-400{ }^{\circ} \mathrm{C}\right)$ and pressure (5-28 MPa). ${ }^{6-8}$ The hot pressure water in the HTL is used for both reaction medium and solvent. The most important product is the high-energy-density black sticky liquid biocrude, which is mainly consisted by hydrocarbons and N/O-containing organic compounds., ${ }^{9,10}$ Previous works have proven that the HTL process can convert up $20-70 \%$ of microalgae (dry weight) into biocrude with a heating value between 28 and $38 \mathrm{MJ} \mathrm{kg}^{-1}$, which is $66-90 \%$ of the heating value of petroleum. However, at present, the obtained biocurde unsatisfactorily contains a relatively high contents of oxygen (10-20\%), nitrogen (3-10\%) and

School of Environment and Natural Resources, Renmin University of China, Beijing, 100872, PR China. E-mail: zhangjl@ruc.edu.cn; Tel: +86-10-62512985

$\dagger$ Electronic supplementary information (ESI) available. See DOI: 10.1039/c7ra08311d leum. ${ }^{11-13}$ When directly applied to petroleum refining fuel or as the fuel, the high oxygen and nitrogen content would be damage to production facility or cause air pollution. ${ }^{\mathbf{1 4 - 1 6}}$ To improve the biocrude yield and reduce the heteroatom content, researchers started the catalyst screening work.

Many catalysts from petroleum industry such as $\mathrm{Pd} / \mathrm{C}, \mathrm{Pt} / \mathrm{C}$, $\mathrm{Ru} / \mathrm{C}, \mathrm{Ni} / \mathrm{SiO}_{2}-\mathrm{Al}_{2} \mathrm{O}_{3}, \mathrm{CoMo} / \gamma-\mathrm{Al}_{2} \mathrm{O}_{3}$, Raney-Ni, HZSM-5 and zeolite have been applied in the HTL of microalgae and the liquefaction process has been intensively investigated. ${ }^{17-22}$ However, these synthetic industrial catalysts required extra cost and caused pollution during the catalyst production. In that case, we believed that a natural clay material catalyst could be greener. Besides, it is widely believed that the fossil fuel petroleum came from ancient fossilized organic materials like algae through the thermochemical process with intense heat and pressure in the lithosphere. During the process, rocks and clays might play a role as catalyst. ${ }^{23-27}$ Since the HTL of microalgae to produce biocurde is much like the formation of petroleum, natural clay materials could be the catalyst to produce the petroleum-like liquid biocrude and provide a better way for catalyst screening.

In this paper, we reported a detailed study on hydrothermal liquefaction of high protein microalgae Spirulina over three kinds of conventional clay catalysts. Effects of catalyst types, reaction temperature, and holding time on the biocrude yield and liquefaction conversion were investigated. The characterization of target product biocrude was tested by element analysis, group component analysis, and GC-MS. 


\section{Materials and methods}

\subsection{Materials}

The HTL feedstock microalgae Spirulina were purchased from Shandong Binzhou Tianjian Biotechnology Co., Ltd. (Shandong, China). Table 1 showed the biochemical information of feedstock. The clay catalysts montmorillonite KSF (CAS 1318-930 ), kaolinite (CAS 1318-74-7), and dolomitic limestone (CAS 1317-65-3) were purchased from Sigma-Aldrich (Shanghai, China). Deionized water was prepared by a Millipore Milli Q UV Plus system. All other chemicals used were of analytic reagent grade and without any further purification.

\subsection{HTL process and product separation}

The HTL experiments were carried out in a $1.8 \mathrm{~L}$ high-pressure stainless reactor (Parr Instruments Co., Moline, PA). In a single round, $120 \mathrm{~g}$ of microalgae, $12 \mathrm{~g}$ of catalyst and $480 \mathrm{~g}$ of deionized water were loaded into the reactor, and the mixtures were well-stirred. After the loading, the reactor was sealed and pumped with $\mathrm{N}_{2}$ three times to remove the air and provide an inert atmosphere. The reactor was heated to the set temperature and held for a certain time.

After completion of the holding time, the reactor was cooled to room temperature $\left(25^{\circ} \mathrm{C}\right)$, and then the exhaust valve was opened to release the pressure. The mixture of liquid and solid products were poured out from the reactor and collected. Dichloromethane (DCM) was used to wash the reactor, and the washing liquor was collected and mixed with products. The products and the washing DCM were filtered, and the solid residue was washed with DCM for three times to remove the DCM-soluble product. After filtering, the liquid mixture was separated into the water-soluble phase and DCM-soluble phase in a separating funnel. The DCM-soluble phase was treated by vacuum distillation at $60^{\circ} \mathrm{C}, 0.05 \mathrm{MPa}$ to remove the DCM. After

Table 1 Analysis results of feedstock ${ }^{a}$

\begin{tabular}{|c|c|}
\hline Analyses & Spiruli \\
\hline \multicolumn{2}{|c|}{ Proximate analysis (wt\%) } \\
\hline Moisture $\mathrm{W}_{\mathrm{ar}}$ & 6.5 \\
\hline Ash $\mathrm{A}_{\mathrm{ar}}$ & 6.8 \\
\hline \multicolumn{2}{|c|}{ Biochemical composition analysis (wt $\%$, daf)ar } \\
\hline Carbohydrates & 23.7 \\
\hline Protein & 66.0 \\
\hline Lipids & 10.3 \\
\hline \multicolumn{2}{|c|}{ Elemental analysis (wt\% daf) $)_{\mathrm{ar}}$} \\
\hline $\mathrm{C}$ & 47.08 \\
\hline $\mathrm{H}$ & 8.77 \\
\hline $\mathrm{O}^{b}$ & 30.58 \\
\hline $\mathrm{N}$ & 9.97 \\
\hline S & 2.08 \\
\hline $\mathrm{H} / \mathrm{C}$ (molar ratio) & 2.23 \\
\hline $\mathrm{O} / \mathrm{C}$ (molar ratio) & 0.49 \\
\hline HHV (MJ kg-1) & 24.94 \\
\hline
\end{tabular}

${ }_{\text {ar }}=$ as received. daf $=$ dry ash free. ${ }^{b}$ Determined by difference. the evaporation, the obtained DCM-removed black viscous liquid product was defined as the aim product biocrude and then was weighted. The solid residue was moved into a drying oven at $105{ }^{\circ} \mathrm{C}$ for $24 \mathrm{~h}$ to remove the water and DCM and then weighted. The weight of organic residue was calculated by the mass difference between the solid residue and the sum of the weight of ash in dry microalgae and the weight of the clay catalyst. The analysis of the gaseous and water-soluble reaction products is beyond the scope of this paper. The experiment without catalyst was named as blank to be used for comparison in this paper. All the liquefaction experiments were repeated for at least three times, and only the average values were presented.

\subsection{Analytic methods of product}

The liquefaction conversion (\%) and biocrude yield ( $Y_{\text {biocrude, }}$ $\%$ ) were calculated by the following formulas (1) and (2), respectively.

Liquefaction conversion $(\%)$

$$
\begin{gathered}
=\left(1-\frac{\text { mass of organic solid residue }}{\text { mass of microalgae }}\right) \times 100 \% \\
Y_{\text {biocrude }}(\%)=\frac{\text { mass of biocrude }}{\text { mass of microalgae }} \times 100 \%
\end{gathered}
$$

The content of asphaltene in biocrude sample was analyzed by ASTM D2007-03(2008) methods. Elements composition of feedstock and biocrude were analyzed by a VARIO EL III elemental analyzer to determine the content of $\mathrm{C}, \mathrm{H}, \mathrm{N}, \mathrm{S}$ element. The $\mathrm{O}$ content was determined by difference. The higher heating value (HHV) of the sample was calculated as described literature, ${ }^{28}$ as shown in formula (3):

$$
\begin{aligned}
\operatorname{HHV}\left(\mathrm{MJ} \mathrm{kg}^{-1}\right)= & (34 \mathrm{C}+124.3 \mathrm{H}+6.3 \mathrm{~N} \\
& +19.3 \mathrm{~S}-9.8 \mathrm{O}) / 100
\end{aligned}
$$

where $\mathrm{C}, \mathrm{H}, \mathrm{O}, \mathrm{N}, \mathrm{S}$ are the element content of carbon, hydrogen, nitrogen, sulfur, and oxygen, respectively.

Energy recovery (ER) was calculated as the formula below to analyze the energy balance, ${ }^{29}$ as shown in formula (4):

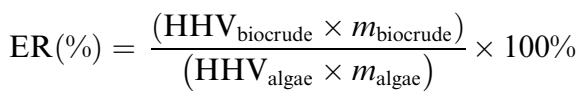

The organic composition of biocrude was analyzed with a gas chromatography-mass spectrometry (GC-MS, QP2010, Shimadzu Co., Tokyo, Japan). GC-MS was equipped with a Varian DB-5 column $(30 \mathrm{~m} \times 0.25 \mathrm{~mm} \times 0.25 \mu \mathrm{m})$. Helium was used as the carrier gas. The injection temperature and interface temperature were set at $250{ }^{\circ} \mathrm{C}$ and $320{ }^{\circ} \mathrm{C}$. The ion source was adjusted to $200{ }^{\circ} \mathrm{C}$. The mass spectrometer was operated in positive electron impact mode (EI) at $70 \mathrm{eV}$. Scan range of mass spectrum was in $\mathrm{m} / \mathrm{z}$ of $20-650$. All chromatogram peaks in spectra were compared with the electron impact mass spectrum from NIST Database (NIST11). Samples were directly diluted with acetone and filtered through a $0.45 \mu \mathrm{m}$ filter. The column temperature was set at $50{ }^{\circ} \mathrm{C}$ for $2 \mathrm{~min}$, then ramped up at a rate 
of $10{ }^{\circ} \mathrm{C} \min ^{-1}$ to $120{ }^{\circ} \mathrm{C}$ and maintained for $1 \mathrm{~min}$, afterward increased to $250{ }^{\circ} \mathrm{C}$ at the same heating rate and maintained for $20 \mathrm{~min}$.

\section{Results and discussions}

\subsection{Effect of catalyst on hydrothermal liquefaction of Spirulina}

After the HTL process, the microalgae was converted into various phase products like biocrude, solid residue, watersoluble aqueous phase product and gas phase product. However, the yields of biocrude were emphasized in recent studies. ${ }^{30}$ This section provides the information about the effect of adding different clay material catalysts on in the hydrothermal liquefaction of Spirulina. The liquefaction processes were carried out at a reaction temperature of $270{ }^{\circ} \mathrm{C}$ and with a holding time of $30 \mathrm{~min}$. Experiment data and further comparison were listed in Table 2 .

As shown in Table 2, three kinds of clay material catalysts all increased the biocrude yield, compared with the blank experiments (30.51\%). The biocrude yields at $270{ }^{\circ} \mathrm{C}$ with different clay catalyst were very close $(39.67 \%, 39.71 \%$ and $40.19 \%$ for montmorillonite, kaolin and dolomitic limestone, respectively). All the clay catalysts showed a favorable effect on the improvement of biocrude yield. The increased liquefaction conversion shown in Table 2 also indicated that adding clay catalysts not only catalyzed the decomposition of the solid organic matters in the microalgae but also enhanced the liquefaction process to produce more biocrude. According to previous studies, the primary compounds in the microalgae are usually liquefied and converted into biocrude in the following order: lipid, protein, and carbohydrate. ${ }^{31}$ As shown in Fig. 1, the obtained biocrude yield with/without clay catalysts were all much higher than the lipid content in the biocurde. The improved biocrude yield should come from the conversion of protein or carbohydrate. Also, after the dosage of clay catalysts, the liquefaction conversion increased about $5 \%$ while the improvement of biocrude

Table 2 HTL results with different catalyst

\begin{tabular}{|c|c|c|c|c|}
\hline & Blank & Montmorillonite & Kaoline & $\begin{array}{l}\text { Dolomitic } \\
\text { limestone }\end{array}$ \\
\hline Biocrude yield (wt\%) & 30.51 & 39.67 & 39.71 & 40.19 \\
\hline $\begin{array}{l}\text { Liquefaction } \\
\text { conversion (\%) }\end{array}$ & 87.54 & 92.75 & 93.11 & 91.97 \\
\hline \multicolumn{5}{|c|}{ Element analysis (wt\%) } \\
\hline $\mathrm{C}$ & 71.75 & 70.12 & 69.45 & 72.06 \\
\hline $\mathrm{H}$ & 8.94 & 9.95 & 9.78 & 9.54 \\
\hline $\mathrm{O}^{a}$ & 11.95 & 12.15 & 13.36 & 10.91 \\
\hline $\mathrm{N}$ & 6.83 & 7.42 & 7.16 & 6.97 \\
\hline $\mathrm{S}$ & 0.53 & 0.36 & 0.25 & 0.52 \\
\hline $\begin{array}{l}\text { Asphaltene } \\
\text { content (\%) }\end{array}$ & 26.9 & 58.1 & 51.5 & 38.7 \\
\hline $\mathrm{HHV}\left(\mathrm{MJ} \mathrm{kg}^{-1}\right)$ & 34.87 & 35.55 & 34.96 & 35.83 \\
\hline Energy recovery (\%) & 42.66 & 58.28 & 55.66 & 57.74 \\
\hline
\end{tabular}

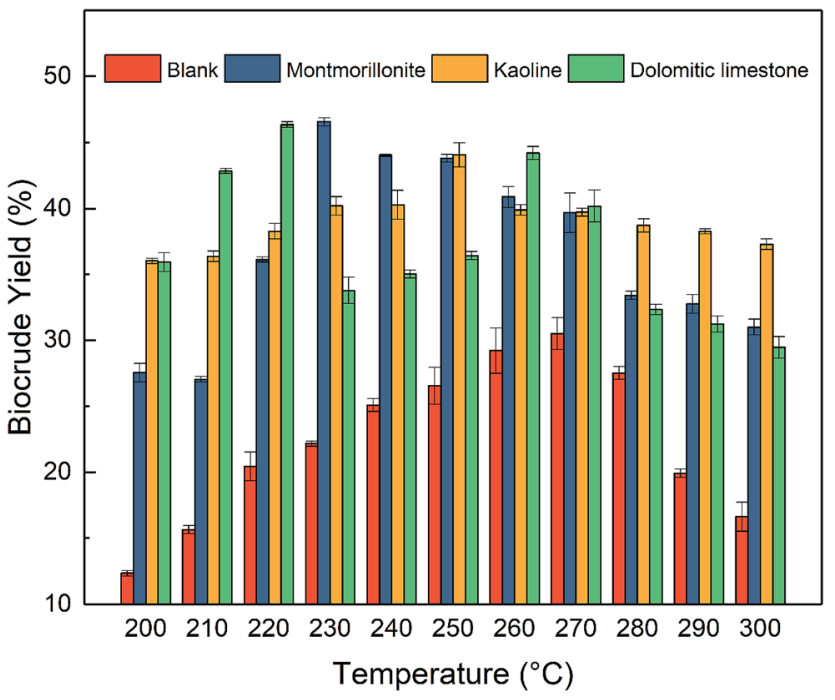

Fig. 1 Effect of reaction temperature on HTL of microalgae over different clay catalysts.

yield was around $10 \%$. The difference suggested that the formation of more biocrude might not only come from the decomposition of microalgae but also be from the condensation reaction of small molecular water-soluble molecules. ${ }^{32}$ As widely known, the asphaltene could be produced by the polymerization of small molecules. The growth of the asphaltene content in biocrude could prove that there must be more repolymerization reactions after adding catalysts. Further element analysis suggested that adding clay catalysts resulted in a pleasing increase of the hydrogen content and slightly reduced the sulfur content in biocrude. The changes of $\mathrm{N}, \mathrm{S}$, and $\mathrm{O}$ heteroatom content could come from a series of reactions, like decarboxylation, deamination, desulfurization, esterification, dehydration condensation, and Maillard reactions, which were associated with the condensation reaction during the formation of asphaltene. Based on the element content in biocrude, the HHVs of biocrude samples were in the range of 34-36 MJ kg ${ }^{-1}$, which was about $85-90 \%$ of the HHV of petroleum. Adding clay catalysts slightly increased the HHV of the biocrude, as shown in Table 2. Moreover, the energy recoveries were all increased by more than $10 \%$ with the three kinds of catalysts. Therefore, clay catalyst did take a positive effect on HTL of microalgae Spirulina.

\subsection{Hydrothermal catalytic liquefaction results with different operating conditions}

Many literature studies have indicated that HTL conditions, like reaction temperature and holding time, were the influential factors of the biocrude yield and the liquefaction conversion. ${ }^{33-35}$ These condition parameters play a decisive role in the decomposing of microalgae and the formation of biocrude. Hence, the influence on the reaction temperature and holding time was studied.

3.2.1. Effect of reaction temperature on HTL with different clay catalysts. Fig. 1 presented the biocrude yield as the 
functions of temperature with different clay catalysts. The HTL experiments were performed with the individual catalyst at the temperature range of $200-280{ }^{\circ} \mathrm{C}$, with an increment of $10{ }^{\circ} \mathrm{C}$ and a holding time of $30 \mathrm{~min}$. The corresponding reaction temperature ranged from 1.98 to $9.85 \mathrm{MPa}$, depending on the final temperatures.

As shown in Fig. 1, with the reaction temperature increasing from 200 to $280^{\circ} \mathrm{C}$, the biocrude yield gradually increased and reached a maximum yield. After that, the biocrude yield gradually decreased with higher temperature. Consequently, from the perspective of biocrude yield, the optimum temperature for the highest biocrude yield with montmorillonite KSF (46.56\%), kaolinite $(44.07 \%)$ and dolomitic limestone $(46.35 \%)$ were 230 , 250 and $220^{\circ} \mathrm{C}$, respectively. The pre-set reaction temperature provided the necessary energy to convert the NAS into biocrude and other byproducts. Rising the reaction temperature in an appropriate range could enhance the conversion process to biocrude. However, when the higher temperature was supplied, the balance between the re-polymerization of small molecules and the cracking of big molecules could be reassigned. The decrease of biocrude yield suggested that the weight of biocrude production became lighter with higher temperature. However, the type of catalyst significantly affected the distribution of solid residue and products of other phases.

Interestingly, there was a second-highest peak of biocurde yield $(44.21 \%)$ with dolomitic limestone as the catalyst at $260{ }^{\circ} \mathrm{C}$. However, the biocrude obtained at a lower temperature with dolomitic limestone showed a better flowability than that obtained at a higher temperature. In the lower temperature experiments, the obtained solid residue remained the form of microalgae while the dark green color of Spirulina changed into dark yellowish-brown. Obviously, the microalgae were not decomposed entirely at a lower temperature. The liquefaction conversions with dolomitic limestone at $220{ }^{\circ} \mathrm{C}$ was less than $80 \%$ also verified this phenomenon. The liquefaction conversion of $66.45 \%$ suggested that the unconverted organic matters in microalgae was more than the hard-to-be-converted carbohydrates. The liquefaction process did produce some DCMsoluble compounds, but the remained biochemical compounds like most carbohydrates or some proteins in the cell of microalgae were not entirely liquefied and converted into biocrude as the form obtained at high temperature. The higher active energy demand for liquefaction of carbohydrates or proteins might explain the results. ${ }^{32}$

The further comparison presented in Table 3 showed the influence of reaction temperature on element composition and asphaltene contents in biocrude. Asphaltene content data suggested that low reaction temperature led to a lower asphaltene content, and the increased temperature resulted in a higher asphaltene content. It seems that the higher temperature prompted the formation of macromolecule compounds like pitch, as described in literature. ${ }^{36}$ Adding clay catalysts increased the asphaltene contents in the biocrude samples by more than $10 \%$ at $270{ }^{\circ} \mathrm{C}$ while the increase of reaction temperature from 220 to $270{ }^{\circ} \mathrm{C}$ led to an asphaltene content growth no more than $10 \%$. The clay catalysts could take the positive catalytic role in the formation of asphaltene, and the influence was more important than the reaction temperature.

Table 3 HTL results under different reaction temperature

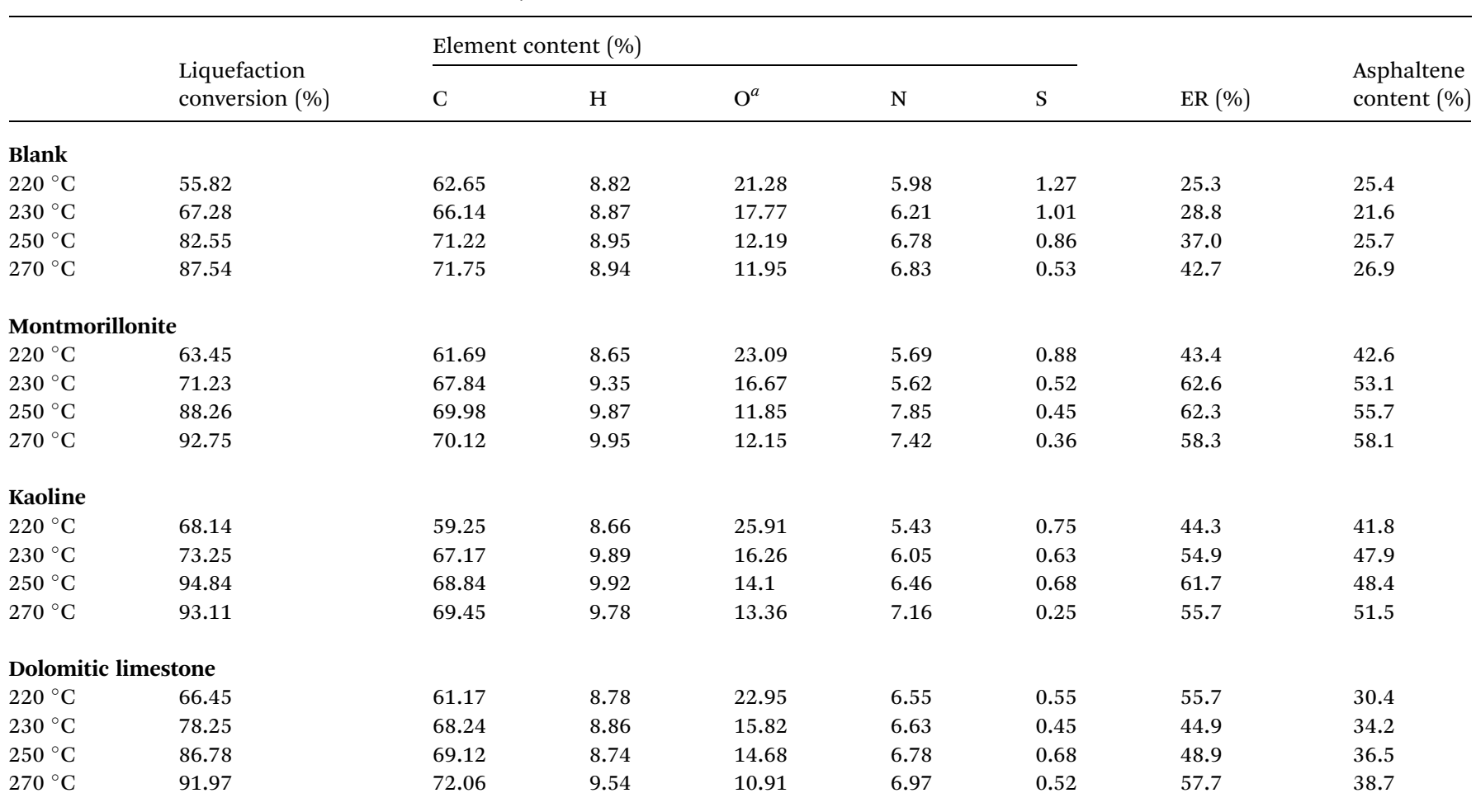

${ }^{a}$ Determined by difference. 
Element analysis presented an approximate increase of carbon and hydrogen content and a decrease of oxygen content, with the increase of the reaction temperature. The changing trend was pleasing for improving a higher heat value and stability of biocrude. Moreover, there was a trend of improvement of energy recovery with higher reaction temperature. Therefore, adding clay catalysts received a higher biocrude yield, a modified liquefaction conversion, and an improved biocrude quality. The

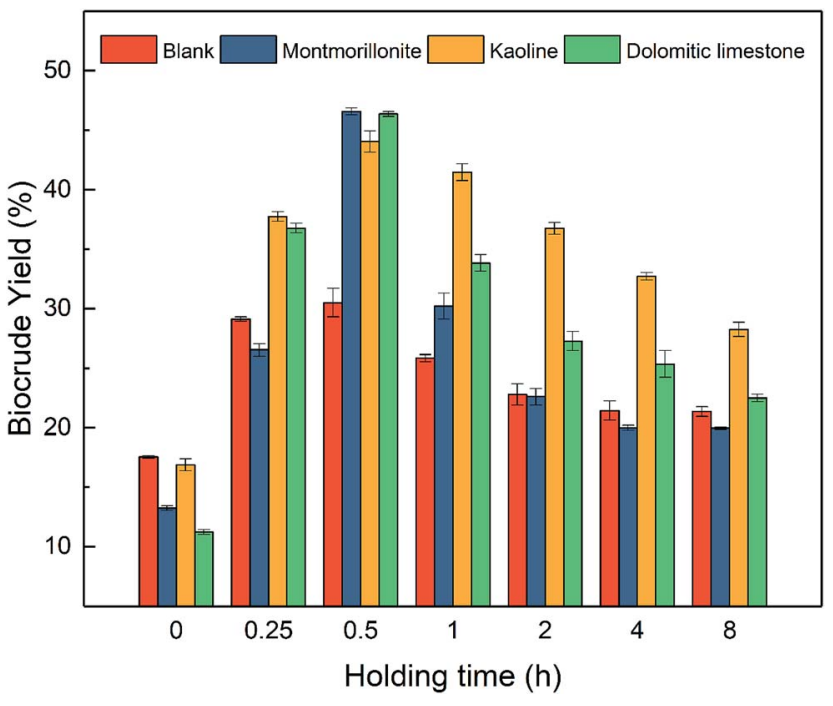

Fig. 2 Effect of holding time on HTL of microalgae over different clay catalysts. temperature significantly influenced the properties and characterization of biocrude.

\subsubsection{Effect of holding time on HTL with different clay} catalysts. Holding times are defined as a period of reacting at a maximum temperature, excluding heating and cooling times. ${ }^{36}$ In our experiments, relations between holding time and biocrude yield or liquefaction conversion was investigated.

As shown in Fig. 2, the holding time experiments suggested that biocrude yields were closely linked to the length of holding time in an appropriate time range. When the holding time was shorter than $0.5 \mathrm{~h}$, lengthening holding time significant improved the biocrude yield. Similar trends were discovered by $\mathrm{Xu}$ and Singh. ${ }^{37,38}$ However, there was a certain threshold of holding time in the liquefaction process. As the biocrude yield peaked at $0.5 \mathrm{~h}$, the further increase of holding time adverted results that the biocrude yield gradually decreased. A similar trend was found in the liquefaction conversion. A holding time expanding from 0 to $0.5 \mathrm{~h}$ increased the liquefaction significantly. However, the holding time between $0.5-8 \mathrm{~h}$ hardly affected the liquefaction conversion. Among various catalyst types, the longer holding time influenced the HTL under montmorillonite catalyst most.

For all liquefaction experiments with or without the clay catalyst, an appropriate holding time, like $0.5 \mathrm{~h}$, could promote the biocrude yield and liquefaction conversion efficiently. It should be noted when the holding time was too short, the liquefaction conversion and biocrude yield were extremely low while the solid residue was hard for separation from the liquid

Table 4 HTL result under different holding time

\begin{tabular}{|c|c|c|c|c|c|c|c|c|}
\hline \multirow[b]{2}{*}{ Holding Time } & \multirow{2}{*}{$\begin{array}{l}\text { Liquefaction } \\
\text { conversion (\%) }\end{array}$} & \multicolumn{5}{|c|}{ Element content (\%) } & \multirow[b]{2}{*}{ ER (\%) } & \multirow{2}{*}{$\begin{array}{l}\text { Asphaltene } \\
\text { content (\%) }\end{array}$} \\
\hline & & $\mathrm{C}$ & $\mathrm{H}$ & $\mathrm{O}^{a}$ & $\mathrm{~N}$ & $\mathrm{~S}$ & & \\
\hline \multicolumn{9}{|l|}{ Blank } \\
\hline $0 \mathrm{~h}$ & 79.64 & 68.99 & 9.05 & 14.31 & 6.98 & 0.67 & 23.84 & 21.3 \\
\hline $0.5 \mathrm{~h}$ & 87.54 & 71.75 & 8.94 & 11.95 & 6.83 & 0.53 & 42.66 & 26.9 \\
\hline $2 \mathrm{~h}$ & 87.56 & 71.82 & 8.98 & 12.14 & 6.54 & 0.52 & 31.91 & 27.5 \\
\hline $8 \mathrm{~h}$ & 88.01 & 72.68 & 9.01 & 11.21 & 6.58 & 0.52 & 30.27 & 26.8 \\
\hline \multicolumn{9}{|c|}{ Montmorillonite } \\
\hline $0 \mathrm{~h}$ & 48.56 & 65.14 & 9.65 & 18.14 & 6.18 & 0.89 & 17.47 & 26.9 \\
\hline $0.5 \mathrm{~h}$ & 71.23 & 67.84 & 9.35 & 16.67 & 5.62 & 0.52 & 62.56 & 53.1 \\
\hline $2 \mathrm{~h}$ & 71.22 & 68.93 & 8.94 & 15.21 & 6.27 & 0.65 & 30.45 & 53.4 \\
\hline $8 \mathrm{~h}$ & 73.69 & 69.72 & 8.85 & 14.64 & 6.37 & 0.42 & 27.04 & 50.7 \\
\hline \multicolumn{9}{|l|}{ Kaoline } \\
\hline $0 \mathrm{~h}$ & 75.65 & 64.68 & 9.97 & 18.61 & 5.98 & 0.76 & 22.39 & 32.1 \\
\hline $0.5 \mathrm{~h}$ & 94.84 & 68.84 & 9.92 & 14.1 & 6.46 & 0.68 & 61.66 & 48.4 \\
\hline $2 \mathrm{~h}$ & 94.87 & 69.51 & 9.84 & 12.97 & 7.12 & 0.56 & 51.81 & 45.6 \\
\hline $8 \mathrm{~h}$ & 93.78 & 69.67 & 9.76 & 12.28 & 7.68 & 0.61 & 39.89 & 47.8 \\
\hline \multicolumn{9}{|c|}{ Dolomitic limestone } \\
\hline $0 \mathrm{~h}$ & 62.45 & 59.17 & 8.93 & 24.25 & 7.01 & 0.64 & 13.25 & 26.7 \\
\hline $0.5 \mathrm{~h}$ & 66.45 & 61.17 & 8.78 & 22.95 & 6.55 & 0.55 & 55.72 & 30.4 \\
\hline $2 \mathrm{~h}$ & 66.68 & 62.88 & 8.77 & 20.93 & 6.86 & 0.56 & 33.64 & 31.2 \\
\hline $8 \mathrm{~h}$ & 69.65 & 63.01 & 8.71 & 21.31 & 6.39 & 0.58 & 27.69 & 28.9 \\
\hline
\end{tabular}

${ }^{a}$ Determined by difference. 
products and kept in the form of microalgae, only with a changed color from dark green to brownish yellow. This results suggested that during the HTL process, most of the original biomolecules (lipids, proteins, and carbohydrates) in microalgae failed to convert into biocrude or any other product phases without enough holding time. On the contrary, if the holding time lasted too long, the decrease of biocrude yield could be observed. We believed this might be attributed to the cracking, steam reforming or decarboxylation reactions which turned the light oil or small molecule compounds in biocrude into the gaseous product, like methane, carbon oxide or carbon dioxide. ${ }^{39,40}$ This explanation is corresponding to the growth of final pressure. At room temperature, the final pressure in the cooled reactor increased from $0.05 \mathrm{MPa}(30 \mathrm{~min})$ to $0.08 \mathrm{MPa}$ (8 h). The increased final pressure suggested that more products of gaseous phase produced by expanding the holding time. ${ }^{41}$ Meanwhile, the element analysis shown in Table 4 also provided a signal about the decreasing trend of oxygen content in biocrude with a longer holding time. This signal could come from the synthesis of $\mathrm{CO}_{2}$ by the decarboxylation of biocrude, as described in previous literature. ${ }^{32}$ However, expanding the holding time requested more energy input for heat preservation, which made the process less economical. Therefore, an appropriate holding time, like $30 \mathrm{~min}$, is favorite to the HTL of Spirulina over clay catalysts.

\subsection{GC-MS characterization of biocrude and the possible reaction pathways}

This section provides the information about molecules presented in the biocrude and how the clay catalysts changed the biocrude. The samples of biocrude obtained at the highest biocrude yield were analyzed by GC-MS to identify the chemical compounds. Obtained chemical compounds with a relative peak area more than $1 \%$ are listed in Table 5 . It should be noted

Table 5 GC-MS results of the biocrude obtained from catalytic HTL over various catalysts

\begin{tabular}{|c|c|c|c|c|c|c|}
\hline \multirow[b]{2}{*}{ No. } & \multirow[b]{2}{*}{ Compounds } & \multirow{2}{*}{$\begin{array}{l}\text { Retention time } \\
(\mathrm{min})\end{array}$} & \multicolumn{4}{|c|}{ Relative content (\%) } \\
\hline & & & Blank & Montmorillonite & Kaoline & Dolomitic limestone \\
\hline 1 & 1,4-Dioxane & 2.408 & 15.33 & - & - & - \\
\hline 2 & 2-Methylpyrazine & 3.691 & 3.67 & - & - & - \\
\hline 3 & 4-Hydroxy-4-methylpentan-2-one & 3.886 & 7.83 & 4.18 & 2.02 & 2.97 \\
\hline 4 & $o$-xylene & 4.218 & - & - & - & - \\
\hline 5 & (2R,3R)-1-tert-Butyl-2,3-dimethylaziridine & 4.702 & - & 3.63 & 2.34 & - \\
\hline 6 & 2,5-Dimethylpyrazine & 4.746 & 3.17 & - & - & - \\
\hline 7 & 3,3,4-Trimethyldecane & 4.802 & 0 & 2.49 & - & - \\
\hline 8 & 2-Methylpentane-2,4-diamine & 5.734 & 2.42 & - & - & - \\
\hline 9 & $(E)$-N-Butylidenebutan-1-amine & 6.475 & 1.94 & - & - & - \\
\hline 10 & 2-Phenyl- $N$-(propan-2-ylidene)ethanamine & 8.38 & - & - & 1.2 & - \\
\hline 11 & Dibenzofuran & 10.124 & - & - & - & 4.06 \\
\hline 12 & $9 H$-Fluorene & 10.595 & - & - & - & 2.75 \\
\hline 13 & Octodecane & 11.05 & - & 7.29 & - & 10.16 \\
\hline 14 & Pentadecane & 11.052 & - & - & 15.6 & - \\
\hline 15 & Hexadecane & 11.057 & 16.82 & - & - & - \\
\hline 16 & 5-Methyl-dihydropyrimidine-2,4(1H,3H)-dione & 11.389 & 4 & - & - & - \\
\hline 17 & $(7 R, 11 R, E)-3,7,11,15$-Tetramethylhexadec-2-ene & 11.918 & - & 2.39 & 8.75 & - \\
\hline 18 & 9-Methylundec-1-ene & 11.924 & 2.12 & - & - & - \\
\hline 19 & Dodecyl pentan-2-yl sulfite & 12.527 & - & 6.49 & - & - \\
\hline 20 & Hexadecanoic acid & 12.604 & - & - & - & 15.78 \\
\hline 21 & Tetradecanoic acid & 12.605 & 7.38 & - & 10.19 & - \\
\hline 22 & $(9 Z, 12 Z)$-Octadeca-9,12-dienoic acid & 13.769 & - & 8.64 & - & 7.87 \\
\hline 23 & $(E)$-Octadec-9-enoic acid & 13.777 & 10.1 & - & - & - \\
\hline 24 & Hexadecanamide & 14.143 & - & 9.54 & 5.3 & 12.85 \\
\hline 25 & Tetradecanamide & 14.151 & 12.69 & - & - & - \\
\hline 26 & $N$-Methyldodecanamide & 14.414 & - & 8.8 & 7.16 & 7.13 \\
\hline 27 & Tridecaneamide & 14.424 & 2.75 & - & - & - \\
\hline 28 & $\mathrm{~N}$-Methyltridecanamide & 14.767 & - & 5.7 & 5.12 & 4.82 \\
\hline 29 & Methyl stearate & 15.871 & - & - & - & 3.16 \\
\hline 30 & $(12 E, 15 E)$-Methyl octadeca-12,15-dienoate & 15.876 & - & 2.88 & - & - \\
\hline 31 & 2-(Hex-5-enyl)oxirane & 15.892 & 3.89 & - & - & - \\
\hline 32 & $N$-Butylstearamide & 16.233 & - & - & - & 5.72 \\
\hline 33 & $N, N$-Diethyldodecanamide & 16.236 & - & 8.6 & 19.57 & - \\
\hline 34 & 1-Morpholinodecan-1-one & 17.711 & - & 17.25 & - & 12.08 \\
\hline 35 & 1-Isothiocyanato-3-methylhexane & 17.732 & 5.89 & - & - & - \\
\hline 36 & 1-(Pyrrolidin-1-yl)dodecan-1-one & 19.158 & - & 5.69 & 4.77 & 3.41 \\
\hline 37 & Undecanal & 21.125 & - & - & - & 4.68 \\
\hline 38 & $N, N$-Bis(2-hydroxyethyl)stearamide & 21.126 & - & 6.43 & 8.06 & - \\
\hline
\end{tabular}




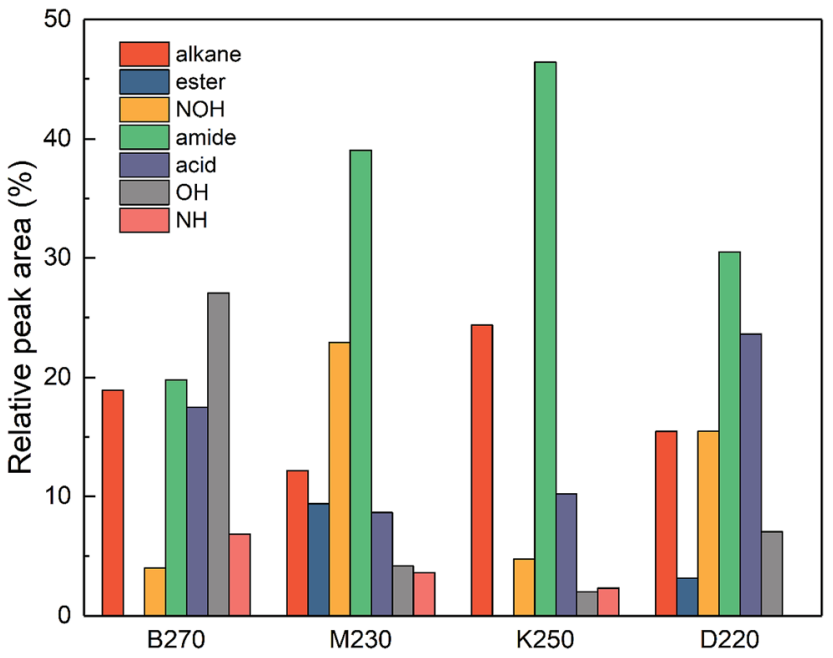

Fig. 3 Group fraction distribution of biocrude with the highest biocurde yield under different clay catalysts. B: blank experiment; $M$ : montmorillonite catalyst; K: kaolin catalyst; $\mathrm{D}$ : dolomitic limestone catalyst. $\mathrm{OH}$ : oxygen-containing-only heterocyclic compound; $\mathrm{NH}$ : nitrogen-containing-only heterocyclic compound; $\mathrm{NOH}$ : oxygenand-nitrogen-containing heterocyclic compound.

that the GC-MS analysis could only identify components which can vapor and pass through the GC column. Those high-boingpoint compounds like asphaltene or thermolabile components could not identify by GC-MS. To simplify the discussion, these identified compounds were classified into seven group: hydrocarbons, esters, fatty acids, fatty acid amides, oxygencontaining-only heterocyclic compounds $(\mathrm{OH})$, nitrogencontaining-only heterocyclic compounds $(\mathrm{NH})$ and oxygenand-nitrogen-containing heterocyclic compounds (NOH). The group distribution of GC-MS identified compounds was presented in Fig. 3.

According to Fig. 3, adding clay catalysts increased the amide and $\mathrm{NOH}$ content while reduced the $\mathrm{OH}$ and $\mathrm{NH}$ content in biocrude. montmorillonite reduced the hydrocarbons and fatty acids content by $35.7 \%$ and $50.6 \%$, respectively. Kaoline catalyst increased the hydrocarbon yield by $28.6 \%$ but decreased the acid yield by $41.7 \%$. The dolomitic limestone catalytic liquefied more fatty acids into biocrude while avoiding the synthesis of alkanes and esters. The possible reaction pathways would contain the next few types: $:^{12,42-44}$ (i) hydrolysis of lipid, protein, and carbohydrates, which explained the formation of fatty acid and other reaction intermediates such as amino acids and alcohols; ${ }^{6,45}$ (ii) esterification, ammonolysis and decarboxylation of fatty acid, which could be the cause of esters, amides and alkanes; ${ }^{22,46,47}$ (iii) annulation reaction from the hydrolysis product of carbohydrates and proteins by themselves or between them, that is why there were plenty of heterocyclic compounds in biocrude; ${ }^{48-50}$ (iv) polymerization to product asphaltene or other macromolecule compounds. ${ }^{51-53}$ It should be noted that there was a obvious competive relation between the formation of easters, fatty acid amides, fatty aicds, and some alkanes. These compounds all come from the fatty aicds from the hydrolysis of lipid and the three types of clay catalysts (montmorillonite, kaoline, and dolomitic limestone) played a different role in the formation of these four kinds of organic compounds. However, it is a pity that only part of the components in biocrude could be identified by GC-MS and current analysis could only provide an approximate composition of the biocrude. Further analysis based on high resolution mass spectrum should be taken in the further.

\section{Conclusion}

In this paper, three kinds of clay materials were introduced as the catalyst into the HTL of high protein microalgae Spirulina. Adding clay catalyst improved the liquefaction conversion and biocrude yield. Research suggested that operating parameters like reaction temperature and holding time were significant for HTL products of Spirulina with clay catalysts. The optimized operating conditions were a holding time of $0.5 \mathrm{~h}$ and an appropriate reaction temperature for the different catalyst (230, 250 and $220{ }^{\circ} \mathrm{C}$ for montmorillonite, kaoline and dolomitic limestone, respectively). The catalyst screening studies would help researchers to understand and improve the catalytic liquefaction of microalgae better.

\section{Conflicts of interest}

There are no conflicts to declare.

\section{Acknowledgements}

This research was financially supported by the fund for building world-class universities (disciplines) of Renmin University of China. Lastly, the authors thank anonymous reviewers for fruitful suggestions.

\section{References}

1 C. Y. Tian, B. M. Li, Z. D. Liu, Y. H. Zhang and H. F. Lu, Renewable Sustainable Energy Rev., 2014, 38, 933-950.

2 A. Demirbas, Energy Convers. Manage., 2010, 51, 2738-2749.

3 L. Gouveia and A. C. Oliveira, J. Ind. Microbiol. Biotechnol., 2009, 36, 269-274.

4 L. Brennan and P. Owende, Renewable Sustainable Energy Rev., 2010, 14, 557-577.

5 A. Marcilla, L. Catala, J. C. Garcia-Quesada, F. J. Valdes and M. R. Hernandez, Renewable Sustainable Energy Rev., 2013, 27, 11-19.

6 A. A. Peterson, F. Vogel, R. P. Lachance, M. Froling, M. J. Antal and J. W. Tester, Energy Environ. Sci., 2008, 1, 32-65.

7 D. López Barreiro, S. Riede, U. Hornung, A. Kruse and W. Prins, Algal Res., 2015, 12, 206-212.

8 S. S. Toor, L. Rosendahl and A. Rudolf, Energy, 2011, 36, 2328-2342.

9 Y. H. Zhu, K. O. Albrecht, D. C. Elliott, R. T. Hallen and S. B. Jones, Algal Res., 2013, 2, 455-464.

10 C. Torri, D. Fabbri, L. Garcia-Alba and D. W. F. Brilman, J. Anal. Appl. Pyrolysis, 2013, 101, 28-34. 
11 Y. Guo, T. Yeh, W. H. Song, D. H. Xu and S. Z. Wang, Renewable Sustainable Energy Rev., 2015, 48, 776-790.

12 Y. Chen, Y. L. Wu, D. R. Hua, C. Li, M. P. Harold, J. L. Wang and M. D. Yang, RSC Adv., 2015, 5, 18673-18701.

13 K. Kumar, S. Ghosh, I. Angelidaki, S. L. Holdt, D. B. Karakashev, M. A. Morales and D. Das, Renewable Sustainable Energy Rev., 2016, 65, 235-249.

14 S. Arvindnarayan, K. K. S. Prabhu, S. Shobana, G. Kumar and J. Dharmaraja, Int. Biodeterior. Biodegrad., 2017, 119, 260272.

15 C. Y. Yang, R. Li, C. Cui, S. P. Liu, Q. Qiu, Y. G. Ding, Y. X. Wu and B. Zhang, Green Chem., 2016, 18, 3684-3699.

16 Z. Chang, P. Duan and Y. Xu, Bioresour. Technol., 2015, 184, 349-354.

17 L. Gao, J. Sun, W. Xu and G. Xiao, Bioresour. Technol., 2017, 225, 293-298.

18 D. L. Barreiro, B. R. Gomez, F. Ronsse, U. Hornung, A. Kruse and W. Prins, Fuel Process. Technol., 2016, 148, 117-127.

19 P. Biller, R. Riley and A. B. Ross, Bioresour. Technol., 2011, 102, 4841-4848.

20 P. G. Duan and P. E. Savage, Ind. Eng. Chem. Res., 2011, 50, 52-61.

21 G. W. Roberts, M. O. P. Fortier, B. S. M. Sturm and S. M. Stagg-Williams, Energy Fuels, 2013, 27, 857-867.

22 J. Zhang, W. T. Chen, P. Zhang, Z. Luo and Y. Zhang, Bioresour. Technol., 2013, 133, 389-397.

23 K. A. Kvenvolden, Org. Geochem., 2006, 37, 1-11.

24 G. P. Glasby, Resour. Geol., 2006, 56, 83-96.

25 V. Simanzhenkov and R. Idem, Crude oil chemistry, CRC Press, 2003.

26 T. Gold, Annu. Rev. Energy, 1985, 10, 53-77.

27 S. R. Hart, Nature, 1984, 309, 753-757.

28 H. Zeb, J. Choi, Y. Kim and J. Kim, Energy, 2017, 118, 116126.

29 S. Yokoyama, A. Suzuki, M. Murakami, T. Ogi, K. Koguchi and E. Nakamura, Fuel, 1987, 66, 1150-1155.

30 K. P. R. Dandamudi, T. Muppaneni, N. Sudasinghe, T. Schaub, F. O. Holguin, P. J. Lammers and S. Deng, Bioresour. Technol., 2017, 236, 129-137.

31 P. Biller and A. B. Ross, Bioresour. Technol., 2011, 102, 215225.
32 P. J. Valdez, V. J. Tocco and P. E. Savage, Bioresour. Technol., 2014, 163, 123-127.

33 S. S. Toor, H. Reddy, S. Deng, J. Hoffmann, D. Spangsmark, L. B. Madsen, J. B. Holm-Nielsen and L. A. Rosendahl, Bioresour. Technol., 2013, 131, 413-419.

34 K. Anastasakis and A. B. Ross, Bioresour. Technol., 2011, 102, 4876-4883.

35 P. Fongarland, N. Essayem and F. Rataboul, Ind. Eng. Chem. Res., 2017, 56, 126-134.

36 Y. Xue, H. Y. Chen, W. N. Zhao, C. Yang, P. Ma and S. Han, Int. J. Energy Res., 2016, 40, 865-877.

37 C. Xu and J. Lancaster, Water Res., 2008, 42, 1571-1582.

38 R. Singh, K. Chaudhary, B. Biswas, B. Balagurumurthy and T. Bhaskar, J. Supercrit. Fluids, 2015, 104, 70-75.

39 T. M. Brown, P. G. Duan and P. E. Savage, Energy Fuels, 2010, 24, 3639-3646.

40 Y. F. Yang, C. P. Feng, Y. Inamori and T. Maekawa, Resour., Conserv. Recycl., 2004, 43, 21-33.

41 F. Wang, Z. Chang, P. Duan, W. Yan, Y. Xu, L. Zhang, J. Miao and Y. Fan, Bioresour. Technol., 2013, 149, 509-515.

42 C. Torri, L. G. Alba, C. Samori, D. Fabbri and D. W. F. Brilman, Energy Fuels, 2012, 26, 658-671.

43 A. Demirbas, Energy Convers. Manage., 2000, 41, 633-646.

44 M. Balat, Energy Sources, Part A, 2008, 30, 649-659.

45 S. M. Changi, J. L. Faeth, N. Mo and P. E. Savage, Ind. Eng. Chem. Res., 2015, 54, 11733-11758.

46 Y. Chen, Y. Wu, P. Zhang, D. Hua, M. Yang, C. Li, Z. Chen and J. Liu, Bioresour. Technol., 2012, 124, 190-198.

47 D. Zhou, L. A. Zhang, S. C. Zhang, H. B. Fu and J. M. Chen, Energy Fuels, 2010, 24, 4054-4061.

48 A. Croce, E. Battistel, S. Chiaberge, S. Spera, F. De Angelis and S. Reale, Chemsuschem, 2017, 10, 171-181.

49 C. Zhang, X. H. Tang, L. L. Sheng and X. Y. Yang, Green Chem., 2016, 18, 2542-2553.

50 A. A. Peterson, R. P. Lachance and J. W. Tester, Ind. Eng. Chem. Res., 2010, 49, 2107-2117.

51 J. Y. Chu, W. K. Jiang, S. B. Wu, L. A. Lucia and M. Lei, Energy Fuels, 2017, 31, 1638-1643.

52 F. A. Atiku, K. D. Bartle, J. M. Jones, A. R. Lea-Langton and A. Williams, Fuel, 2016, 182, 517-524.

53 L. Li, Q. You, S. Y. Wu, S. Huang, Y. Q. Wu and J. S. Gao, J. Energy Inst., 2016, 89, 335-345. 